\title{
Mitigation of alkaline mine drainage in a natural wetland system
}

\author{
J. Kelly ${ }^{1}$, P. Champagne ${ }^{2}$ \& F. Michel ${ }^{1}$ \\ ${ }^{I}$ Department of Earth Sciences, Carleton University, Canada \\ ${ }^{2}$ Department of Civil Engineering, Queen's University, Canada
}

\begin{abstract}
Many studies have focused on the generation and mitigation of acidic drainage generated when sulfide bearing material is exposed to the atmosphere and undergoes oxidation. Neutral or alkaline mine drainage can be produced from mining waste containing little or no sulfides, and such drainage can also contain elevated metal concentrations, potentially impacting receiving environments. The goal of this study was to characterize the biogeochemical interactions occurring throughout a natural wetland located in the Farr Creek drainage area in Cobalt Canada and to evaluate the ability of the system to effectively attenuate alkaline mine drainage. The biological characterization of the sediment samples demonstrated the presence of acid producing bacteria in consistent numbers with sulphate reducing bacteria and iron reducing bacteria. The data suggested that the acid produced by these active bacterial populations was immediately neutralized by the dissolution of carbonate minerals within the tailings, yielding a neutral to alkaline drainage. The distribution of metals including $\mathrm{As}, \mathrm{Co}, \mathrm{Cu}$, and $\mathrm{Zn}$ throughout the sediments, pore water, and vegetation samples collected at various core locations the metal mass was primarily bound in the sediments or adsorbed onto organic matter or oxide fractions of the sediments. Phytoremediation processes involving Typha latifolia were shown to attenuate metals, particularly $\mathrm{Cu}$ and $\mathrm{Zn}$. Adsorption onto organic matter and oxides was another attenuation pathway that significantly improved metal retention. Iron and sulfate reduction were also found to lead to the formation of metal sulfide precipitates, thereby immobilizing the metals.

Keywords: wetland, alkaline mine drainage, heavy metals, sequential extraction, phytoremediation, sulphate reducing bacteria, iron reducing bacteria, acid producing bacteria, Typha latifolia.
\end{abstract}




\section{Introduction}

Anthropogenic sources of metals, including mining wastes, runoff waste streams, and air fall deposition from industrial operations, are becoming increasingly an issue for contamination of downstream environments and health impacts to aquatic species and humans. Acid mine drainage (AMD), which results from the oxidation of sulfide bearing material in waste rock or tailings, has received considerable attention. The oxidation of sulfides, which may be catalyzed by microbial populations, produces sulfuric acid, which can result in extremely low $\mathrm{pH}$ waters and enhance heavy metal dissolution. Metals are typically more soluble under low $\mathrm{pH}$ conditions due to the increased competition between protons and metal cations for organic ligands (Schnoor [1]). The dissolved metals have the potential to migrate offsite resulting in potential negative impacts to both humans and aquatic organisms. The acidity produced can potentially be neutralized if there is adequate carbonate minerals present in the tailings and mixing waters, resulting in a net neutral or alkaline mine drainage (NAMD). NAMD can also be produced from mining wastes containing little to no sulfides. Such drainage, although non-acidic, can also contain elevated dissolved metal concentrations, which can potentially impact receiving environments.

Historically many mining companies have used active treatment options for mitigating impacts to the environment as a result of acid mine drainage. These options typically involved chemical additions of neutralizing agents such as lime, which was quite expensive in the long-term. This sparked the movement towards passive treatment options, one of which is the use of constructed or natural wetlands to attenuate the metals. As a result, it is important to characterize metal distributions and transformations in aquatic environments to better understand the geochemical and biological processes regulating transformations in these environments. The main objective of this research was to characterize the biogeochemical interactions occurring throughout a natural wetland receiving NAMD and to evaluate the ability of the wetland in the attenuation of metals.

The study area is located in the Farr Creek drainage area, in Cobalt, Canada. The wetland area investigated is confined to a relatively narrow northeast oriented valley that is bounded to the south by Crosswise Lake and the remnants of a gravel dam, and bounded to the north by a water level control dam. Alkaline tailings underlie the entire study area as well as upgradient of the study area. Mill Creek, which transports metal loadings from several upstream tailings deposits and organic loadings from the municipal wastewater lagoon flows into Farr Creek as shown on Figure 1. The northern portion of the area is maintained under a water cover for much of the open water season, whereas the southern portion of the area is relatively dry throughout the summer and fall. This is further evidenced by the establishment of grasses and sedges in the drier areas, while waterlogged areas are primarily populated with cattails (Typha latifolia). 


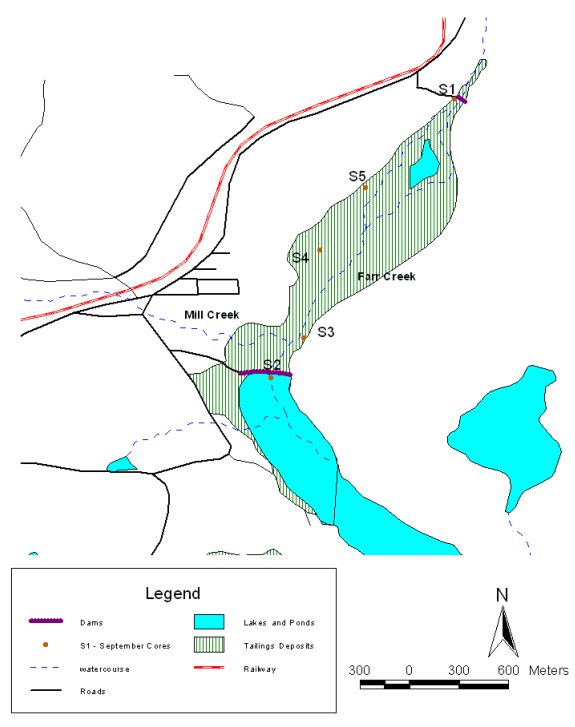

Figure 1: $\quad$ Site plan indicating core sample locations.

\section{Experimental approach}

\subsection{Field sampling}

Five $5 \mathrm{~cm}$ diameter $\mathrm{x}$ up to $1.4 \mathrm{~m}$ long sediment cores were collected from the study area in September 2004 (Figure 1). The cores were capped and sealed from the atmosphere throughout the extraction process. They were kept in a refrigerator and transported in coolers with icepacks to ensure the samples remained below $4^{\circ} \mathrm{C}$ until they were prepared for analysis.

\subsection{Laboratory methods}

Sediment samples were collected from the 5 cores at approximately $25 \mathrm{~cm}$ intervals and analyzed for acid producing bacteria (APB), iron reducing bacteria (IRB) and sulfate reducing bacteria (SRB), sequentially extracted metals (SEM), water content (WC), and organic matter (OM) content. Pore water was extracted from the remaining sediment samples by ultracentrifugation and analyzed for alkalinity, $\mathrm{pH}$, dissolved oxygen (DO), Fe(II), sulfate, sulfide, and dissolved metals. Cattail shoot samples, collected near each of the monitoring wells, were analyzed for metals.

The most probable number (MPN) technique was used to estimate the number of APB, IRB, and SRB in each sample. MPN values were calculated for each set of samples from statistical tables (Cochran [2]) and the results were expressed as colony forming units per gram of sediment dry weight (CFU/gdw). Ten different dilutions, at $1 \mathrm{~mL}$ in $10 \mathrm{~mL}$ were completed with 5 replicates of each dilution. 
Sixteen sediment section samples taken at depths corresponding to the microbiology samples, were analyzed in duplicate for metals using a SEM procedure outlined by Tessier et al. [3] where the extracted metals are separated into five fractions: exchangeable, bound to carbonates, bound to $\mathrm{Fe}$ and $\mathrm{Mn}$ oxides, bound to OM, and residual fraction. Seven cattail (T. latifolia) shoot samples were washed with deionized water, broken into small pieces and crushed with a mortar and pestle. Thirty $\mathrm{mL}$ of $4: 1 \mathrm{HNO}_{3}: \mathrm{HCl}$ mixture was added to $200 \mathrm{mg}$ of ashed cattail shoots. The mixture was digested at $100-130^{\circ} \mathrm{C}$ until the solution became clear. Prepared sequential extraction and vegetation samples were stored below $4^{\circ} \mathrm{C}$ until further analysis and the metals in the samples were analysed by ICPMS.

\section{Results}

\subsection{Sequential Extraction of Metals (SEM)}

Figures 2(a)-(d) present the results of the SEM for selected metals from the 5 cores. Arsenic was predominantly associated with the residual fraction, ranging from 35 to $75 \%$, while the oxide fraction ranged from less than $5 \%$ to $31 \%$ and generally decreased with depth. The fraction of As associated with the OM fraction of the sediment ranged from 10 to $35 \%$. Cobalt was strongly associated with the OM fraction of the sediment, ranging from 22 to $80 \%$. Cobalt was also associated with the residual fraction, ranging from 5 to $40 \%$. Cobalt associated with the oxide fraction ranged from less than $5 \%$ to $32 \%$ and generally decreased with depth. Cobalt associated with the carbonate fraction of the sediment ranged from 8 to $30 \%$. Cobalt has been shown to have an affinity for carbonates, thus, it is likely that there was competition for sorption sites between the carbonate and other fractions of the sediment. Copper was primarily associated with the residual fraction of the sediment, ranging from 10 to $50 \%$, as well as the OM fraction of the sediment, 40 to $85 \%$. Zinc was predominantly associated with the residual fraction, ranging from 15 to $65 \%$. Zinc associated with the oxides fraction ranged from less than 10 to $25 \%$ and generally decreased with depth. Zinc associated with the OM fraction of the sediment ranged from 35 to $45 \%$.

\subsection{Pore water chemistry}

Figures 3(a)-(h) display porewater concentration profiles with depth. In core S2, both As and Co concentrations increased with depth, while in cores S3 and S5, As and Co concentrations increased to a depth of $50 \mathrm{~cm}$ and then decreased. In cores S1 and S4, no observable trends were noted. For cores S3, S4, and S5, Cu concentrations increased to a depth of $50 \mathrm{~cm}$ and then decreased. There were no observable $\mathrm{Cu}$ trends with depth in cores $\mathrm{S} 1$ and S2. Zinc concentrations increased with depth in cores S1 and S3. In core S5, Zn showed increasing concentrations to a depth of $50 \mathrm{~cm}$, followed by decreases, while in core $\mathrm{S} 4 \mathrm{Zn}$ decreased with depth. In core S2, Zn showed no observable trend. Calcium values generally remained fairly constant with depth at all core locations. 

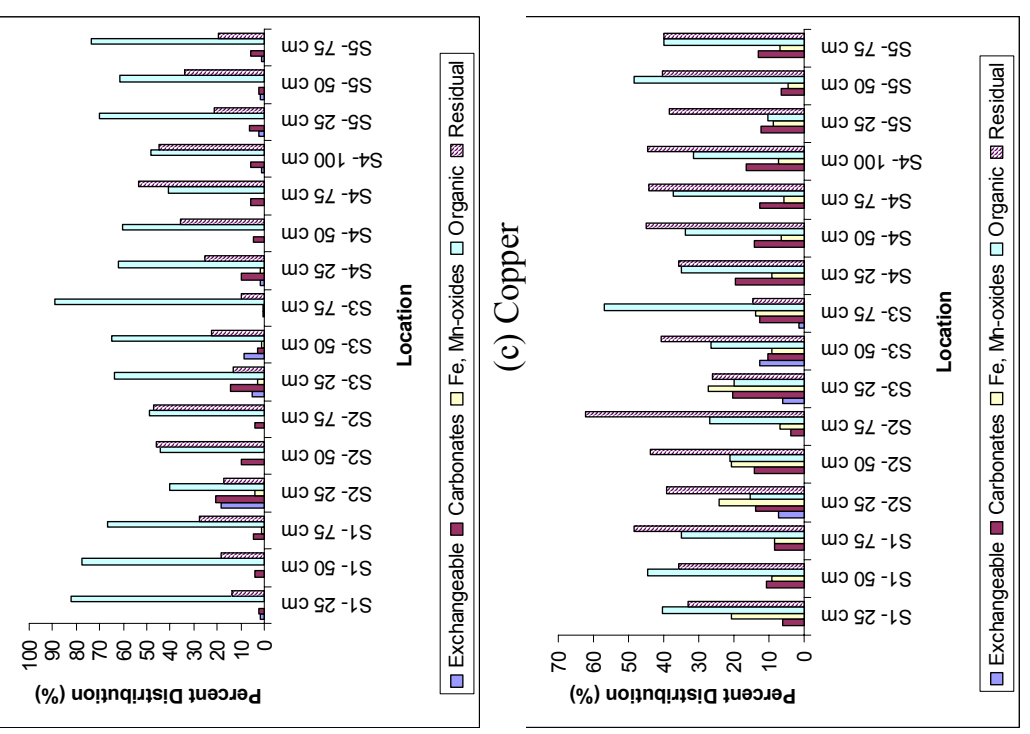

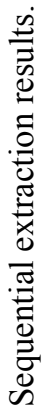
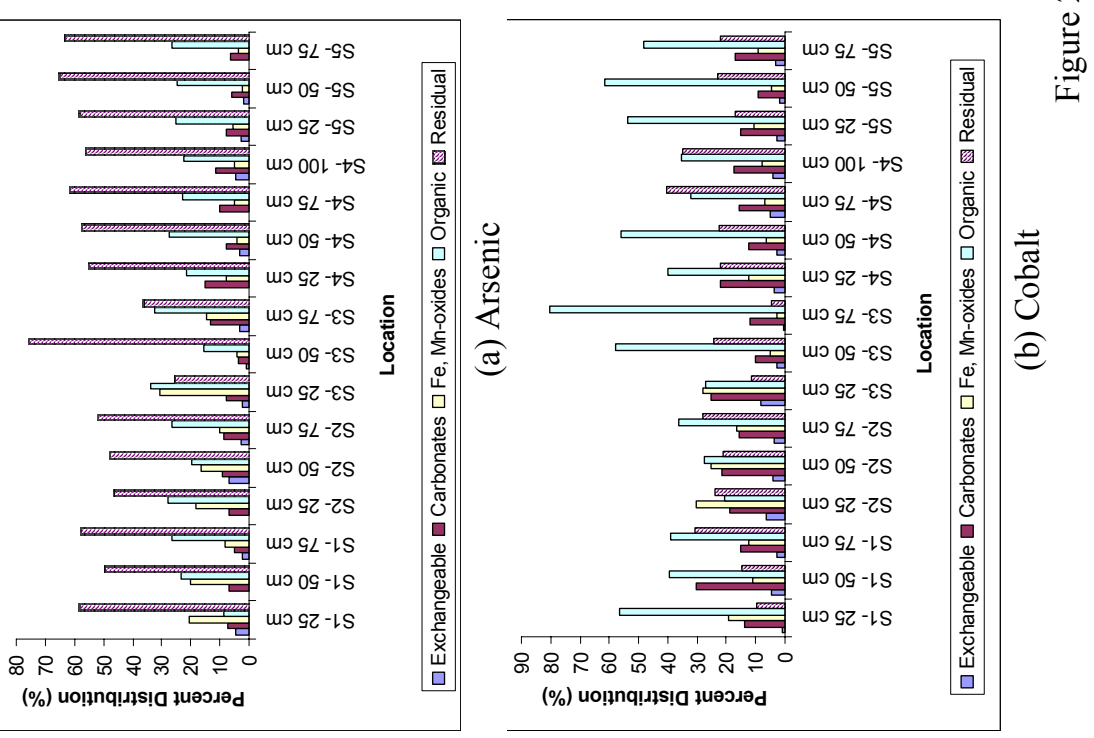

WIT Transactions on Ecology and the Environment, Vol 89, (C) 2006 WIT Press www.witpress.com, ISSN 1743-3541 (on-line) 
120 Geo-Environment and Landscape Evolution II

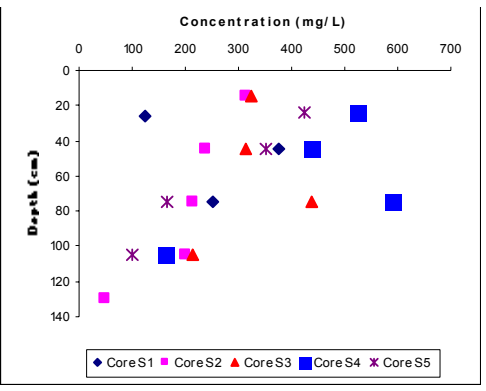

(a) Sulphate

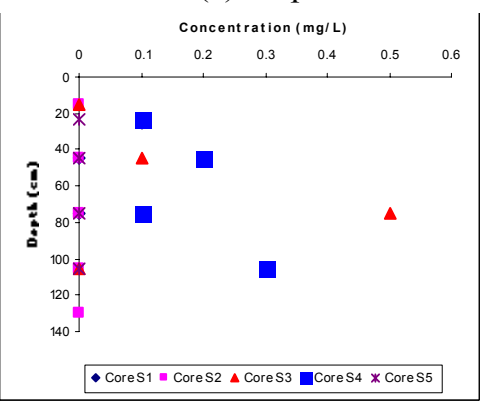

(c) Ferrous iron

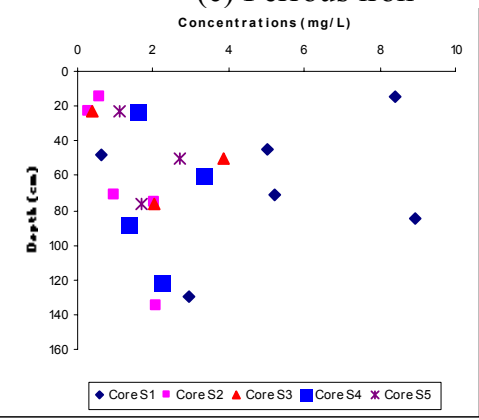

(e) Arsenic

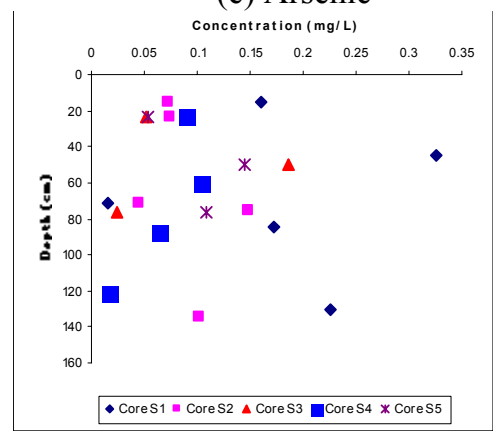

(g) Copper

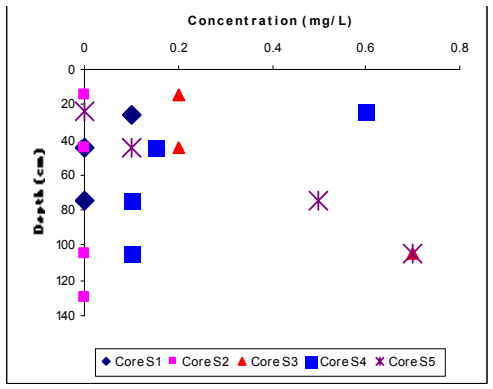

(b) Sulphide

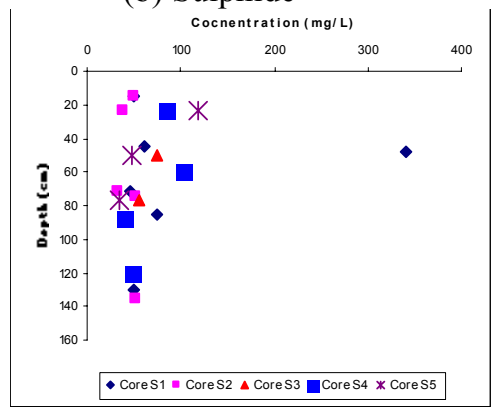

(d) Calcium

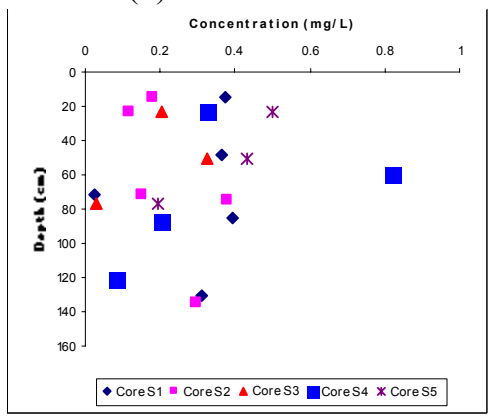

(f) Cobalt

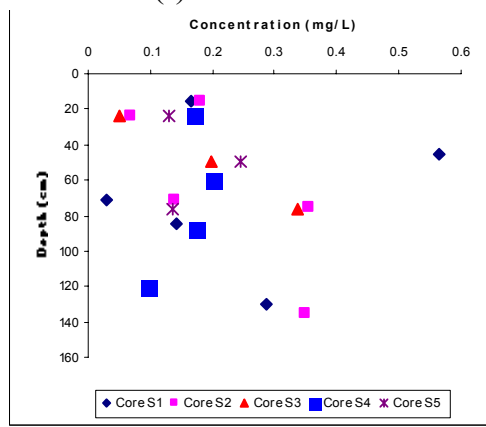

(h) Zinc

Figure 3: Porewater concentrations. 
A reduction in sulfate concentrations with depth was observed in all of the cores. Increasing or measurable $\mathrm{Fe}(\mathrm{II})$ and $\mathrm{HS}^{-}$concentrations with depth were only noted in cores S3, S4, and S5, a further indication of the development of reducing conditions with depth. Porewater DO concentrations remained fairly consistent with depth, ranging from 1.50 to $2.15 \mathrm{mg} / \mathrm{L}$. The $\mathrm{pH}$ values were also relatively consistent throughout the porewater profile, averaging 7.0.

\subsection{Vegetation}

Table 1 presents the results of selected metal extractions from the T. latifolia leaf samples collected. Significant concentrations of selected metals were taken up into the leaf samples. Higher metal concentrations were extracted from leaf samples collected near the wetland inlet, which was expected due to higher metal loading in this area, and is supported by other studies (O'Sullivan et al. [4]; Miller et al. [5]).

Table 1: $\quad$ Extracted metal concentrations from T. latifolia.

\begin{tabular}{|c|c|c|c|c|c|c|c|c|c|}
\hline Sample ID & $\begin{array}{c}\text { Element } \\
\text { Units }\end{array}$ & $\begin{array}{c}\mathbf{A l} \\
\mathrm{ppm}\end{array}$ & $\begin{array}{c}\mathbf{A s} \\
\mathrm{ppm}\end{array}$ & $\begin{array}{c}\text { Co } \\
\text { ppm }\end{array}$ & $\begin{array}{c}\mathrm{Cr} \\
\mathrm{ppm}\end{array}$ & $\begin{array}{c}\mathbf{C u} \\
\text { ppm }\end{array}$ & $\begin{array}{c}\mathrm{Fe} \\
\mathrm{ppm}\end{array}$ & $\begin{array}{l}\text { Mn } \\
\text { ppm }\end{array}$ & $\begin{array}{c}\mathrm{Zn} \\
\mathrm{ppm}\end{array}$ \\
\hline INLET(1) & $\mathrm{mg} / \mathrm{l}$ & 4280 & 182 & 171 & 22.5 & 19.7 & 3020 & 663 & 98.1 \\
\hline Core S1 & $\mathrm{mg} / \mathrm{l}$ & 95.0 & & & & 13.8 & 145 & 336 & 52.2 \\
\hline Core S1 & $\mathrm{mg} / \mathrm{l}$ & 111 & & & 13.1 & 10.3 & 180 & 229 & 66.6 \\
\hline Core S3 & $\mathrm{mg} / \mathrm{l}$ & 201 & 146 & 10.00 & 11.3 & 11.3 & 335 & 678 & 67.5 \\
\hline Core S5 & $\mathrm{mg} / \mathrm{l}$ & 138 & 184 & & 10.0 & 7.50 & 212 & 375 & 50.3 \\
\hline Core S4 & $\mathrm{mg} / \mathrm{l}$ & 872 & & 23.1 & 15.0 & 14.4 & 1050 & 438 & 65.3 \\
\hline $\begin{array}{l}\text { Downstream of } \\
\text { Confluence with } \\
\text { Mill Creek }\end{array}$ & $\mathrm{mg} / \mathrm{l}$ & 302 & 80.0 & 13.4 & & 15.6 & 380 & 218 & 75.0 \\
\hline
\end{tabular}

Table 2: $\quad$ Microbiological enumeration results.

\begin{tabular}{|c|c|c|c|c|c|c|c|c|c|}
\hline $\begin{array}{c}\text { Depth } \\
\text { (cm) }\end{array}$ & \multicolumn{3}{|c|}{ Core S1 } & \multicolumn{3}{c|}{ Core S2 } & \multicolumn{3}{c|}{ Core S3 } \\
\cline { 2 - 9 } & APB & IRB & SRB & APB & IRB & SRB & APB & IRB & SRB \\
\hline 25 & $1.10 \mathrm{E}+05$ & $1.70 \mathrm{E}+04$ & $2.20 \mathrm{E}+02$ & $4.90 \mathrm{E}+04$ & $1.40 \mathrm{E}+04$ & $2.20 \mathrm{E}+03$ & $3.30 \mathrm{E}+04$ & $2.30 \mathrm{E}+04$ & $2.20 \mathrm{E}+05$ \\
50 & $7.00 \mathrm{E}+06$ & $2.20 \mathrm{E}+04$ & $7.90 \mathrm{E}+05$ & $4.90 \mathrm{E}+02$ & $1.70 \mathrm{E}+03$ & $4.90 \mathrm{E}+03$ & $1.30 \mathrm{E}+04$ & $4.60 \mathrm{E}+02$ & $3.30 \mathrm{E}+04$ \\
75 & $3.30 \mathrm{E}+04$ & $1.10 \mathrm{E}+03$ & $1.30 \mathrm{E}+05$ & $4.90 \mathrm{E}+03$ & $1.40 \mathrm{E}+02$ & $7.90 \mathrm{E}+02$ & $1.30 \mathrm{E}+05$ & $1.10 \mathrm{E}+04$ & $4.90 \mathrm{E}+04$ \\
100 & & & & & & & & & \\
\hline
\end{tabular}

\begin{tabular}{|c|c|c|c|c|c|c|}
\hline Depth & \multicolumn{3}{|c|}{ Core S4 } & \multicolumn{3}{c|}{ Core S5 } \\
\cline { 2 - 7 }$(\mathbf{c m})$ & APB & IRB & SRB & APB & IRB & SRB \\
\hline 25 & $7.90 \mathrm{E}+03$ & $7.90 \mathrm{E}+02$ & $2.20 \mathrm{E}+02$ & $1.30 \mathrm{E}+05$ & $1.80 \mathrm{E}+03$ & $3.50 \mathrm{E}+04$ \\
50 & $2.30 \mathrm{E}+04$ & $7.90 \mathrm{E}+02$ & $1.10 \mathrm{E}+02$ & $2.30 \mathrm{E}+03$ & $3.30 \mathrm{E}+02$ & $2.20 \mathrm{E}+03$ \\
75 & $4.90 \mathrm{E}+04$ & $1.30 \mathrm{E}+02$ & $2.80 \mathrm{E}+04$ & $7.90 \mathrm{E}+02$ & $1.30 \mathrm{E}+02$ & $2.20 \mathrm{E}+03$ \\
100 & $7.90 \mathrm{E}+04$ & $3.30 \mathrm{E}+02$ & $2.30 \mathrm{E}+04$ & & & \\
\hline
\end{tabular}

\subsection{Microbiology}

Table 2 presents the results from the bacterial enumerations. There appear to be equally strong numbers of acid producing (oxidizing) and reducing bacteria, with populations ranging from $10^{2}$ to $10^{6} \mathrm{MPN} /$ gram dry weight. The presence of all three types of microorganisms throughout the wetland and at relatively 
consistent concentrations with depth at each core location may suggest that both oxic and anoxic conditions exist throughout the wetland.

\section{Discussion}

This natural wetland appears to be an overall sink for metals, with the majority of the metals being tied up in the sediments or being taken up into the leaves of Typha latifolia. A detailed mass balance would be required to confirm this. In this study, results from the SEM indicated that most of the metals were associated with the residual and OM fractions of the sediment. The residual fraction accounts for silicate minerals and sulfides. This is important since one of the sinks for select metals is the formation of metal sulfide precipitates under reducing conditions. Metals associated with the exchangeable fraction are typically highly mobile and are often correlated with the cation exchange capacity of the sediment (Gambrell et al. [6]). The surfaces of oxides and OM are also prime adsorption sites for metals. Previous studies (Fuller [7]; Lagmuir et al. [8]; Soprovich [9]) have shown that As readily adsorbs to or coprecipitates with $\mathrm{Fe}$ and Mn oxides. The results from the SEM indicated that much of the Fe was associated with the residual fraction of the sediment and not the oxide fraction, while much of the As was associated with the residual and OM fractions of the sediment. Thus, it would appear that given the presence of adequate $\mathrm{Fe}$ and $\mathrm{Mn}$ oxides under oxidizing conditions and adequate sulfides or OM under reducing conditions, As is likely to be well attenuated in this wetland. Zinc and $\mathrm{Cu}$ were predominantly associated with the OM and residual fractions of the sediments. Cobalt was primarily associated with the residual fraction, however, it was also significantly associated with carbonates. Cobalt has known affinities for carbonates (Brookings [10]) and therefore competition for sorption sites between $\mathrm{OM}$ and carbonates are likely.

The porewater sulfate and sulfide concentration profiles indicated that sulfate reduction was occurring throughout the wetland. The microbiology results identified the presence of APB populations in consistent numbers with the SRB and IRB populations. This may indicate that all these bacteria are active and the acid produced by these populations is immediately neutralized by the dissolution

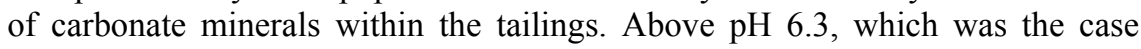
throughout much of the study area, the dissolution of one mole of calcite consumes one mole of $\mathrm{H}^{+}$(Blowes et al. [11]). This would also account for the elevated dissolved concentrations of $\mathrm{Ca}^{2+}$ in the pore water. It is also possible that APB populations are supported at depth throughout the wetland in the vicinity of vegetation root zones. Oxygen is transported by wetland plants to the root zones generating localized zones of oxidation. This could allow for sustainable populations of APBs throughout the wetland. In regions located away from the root zones, conditions are likely anoxic, which are favourable for biogenic iron and sulfate reduction. It is also likely from the microbiology results that there is considerable competition between bacterial species for organic substrates. This was supported by changes in population trends at different locations in the study area, where small changes in sulfate and $\mathrm{Fe}(\mathrm{II})$ 
concentrations occurred. Prior studies have shown competitiveness between SRB and IRB, which appears to be dependent on electron donor availability and pore water chemistry (Fortin, pers. comm..). It should also be noted that Fe reduction can occur both biotically and abiotically, while sulfate reduction can only be mediated by SRB.

The results from the extraction of metals from $T$. latifolia leaf samples indicated that up to $20 \%$ of the total mass of metals was taken up by the leaves. Previous studies have reported metal uptake in both the leaves and root zones of T. latifolia and found much higher percentages of metals associated with the roots than the leaves (Jackson et al. [12]). This suggests that phytoremediation may be an even more powerful source of metal immobilization in this wetland. There has been conflicting research on the ability of wetland plants to immobilize metals in the long term. This is in part due to the fact that plants transport oxygen to their root zones generating a zone of radial oxygen loss, which results in the generation of localized oxic conditions in the immediate vicinity of the roots, resulting in the oxidation of reduced sulfur and iron species. Under these conditions metals such as As and Co may adsorb or coprecipitate with the Fe oxides, however, metals such as $\mathrm{Zn}$ would likely remain mobilized in the dissolved state (Jacob and Otte [13, 14]). Background conditions were not known for the $T$. latifolia in the area, which would have been useful in determining the degree of metal uptake by $T$. latifolia as a direct result of the mine tailings deposits. However, the vegetation was flourishing in the area and thus it was not expected that the presence of metals at these concentrations were having a negative effect on T. latifolia. It is possible, however, that the growth of other wetland plants was inhibited due to elevated metal loading to the wetland system. There was also considerable variability between sample locations. This could most likely be attributed to variations in metal loadings at each location.

\section{Conclusions}

The data collected suggest that this is a relatively stable system. Should the current state of the system change, such as the input of a waste stream elevated in organic substrate, it is likely that a considerable amount of the metals retained within this system would become mobilized. Over time, the geochemical processes regulating metal mobilizations throughout the system would change, resulting in different biogeochemical controls on the metals throughout this system. Alkaline drainage systems are geochemically different than acidic drainage systems. Alkaline systems can immobilize metals under oxic conditions, such as adsorption onto OM or oxide precipitates or uptake by wetland vegetation, and anoxic conditions via microbial transformations, such as biogenic sulfate reduction, generating reduced metal sulfide precipitates. Acidic drainage systems typically require the formation of strongly reducing conditions in order to immobilize metals. These results have demonstrated the importance of considering the geochemical conditions of the wetland system treating the mine drainage, as well as having a detailed understanding of the metals of 
concern within the mining waste, as these will geochemically interact based on redox conditions, presence of sulfides, Fe and $\mathrm{Mn}$ oxides, and organic matter.

\section{References}

[1] Schnoor, J., Modeling trace metals (Chapter 8). Environmental Modeling: Fate \& Transport of Pollutants in Water, Air, Soil, eds. J. Schnoor \& A. Zehnder, Wiley, New York, 381-451, 1996.

[2] Cochran, W.G., Estimation of bacterial densities by means of the most probable number. Biometrics, 6, pp. 105-116, 1950.

[3] Tessier, A., Fortin, D., Belzile, N., DeVitre, R, \& Leppard, G.G., Metal sorption to diagenic iron \& manganese oxyhydroxides \& associated organic matter: narrowing the gap between field \& laboratory measurements. Geochimica et Cosmochimica Acta, 60, pp. 387-404, 1996.

[4] O'Sullivan, A.D., Moran, B.M., \& Otte, M.L., Accumulation \& fate of contaminants in substrates of wetlands constructed for treating mine wastewater. Water, Air, \& Soil Pollution, 157, pp. 345-364, 2004.

[5] Miller, W., McFee, W., \& Kelly, J., Mobility and retention of heavy metals in sandy soils. J.Environmental Quality, 12(4), pp. 579-584, 1983.

[6] Gambrell, R.P., Wiesepape, J., Patrick Jr., W., \& Duff, M., The effects of $\mathrm{pH}$, redox, and salinity on metal release from a contaminated sediment. Water, Air, \& Soil Pollution, 57-58, pp. 359-367, 1991.

[7] Fuller, J., Surface chemistry of ferrihydrite: Part 2. Kinetics of arsenate adsorption and coprecipitation. Geochimica et Cosmochimica Acta, 57, pp. 2271-2282, 1993.

[8] Lagmuir, D., Mahoney, J., MacDonald, A., \& Rowson, J., Predicting arsenic concentrations in the porewaters of buried uranium mill tailings. Geochimica et Cosmochimica Acta, 63(19/20), pp. 3379-3394, 1999.

[9] Soprovich, E., Arsenic Release from Oxide Tailings Containing Scordite, $\mathrm{Fe}$-Ca Arsenates, \& As-Containing Geothites. Environmental Protection Branch-Yukon Division, Environment Canada, Whitehorse, Yukon, 1995.

[10] Brookings, D.G., Eh-pH Diagrams for Geochemistry. Springer-Verlag, USA, 1988.

[11] Blowes, D.W., Jambor, J.L., \& Hanton-Fong, C.L., Geochemical, mineralogical and microbiological characterization of a sulfide-bearing carbonate-rich gold mine tailings impoundment, Joutel, Quebec. Applied Geochemistry, 13(6), pp. 687-705, 1998.

[12] Jackson, L.J., Kalff, J., Rasmussen, J.B., Sediment pH \& redox potential affect the bioavailability of $\mathrm{Al}, \mathrm{Cu}, \mathrm{Fe}, \mathrm{Mn} \& \mathrm{Zn}$ to rooted aquatic macrophytes. Can. J. Fish \& Aquatic Science, 50, pp. 143-148, 1993.

[13] Jacob, D.L., Otte, M.L., Long-term effects of submergence and wetland vegetation on metals in a 90 year old abandoned $\mathrm{Pb}-\mathrm{Zn}$ mine tailings pond. Environmental Pollution, 130, pp. 337-365, 2004.

[14] Jacob, D.L., Otte, M.L., Influence of Typha latifolia \& fertilization on metal mobility in two different $\mathrm{Pb}-\mathrm{Zn}$ mine tailings types. Science of the total environment, 333, pp. 9-24, 2004. 